\title{
Challenges Faced by Teachers in Online Teaching during the Pandemic
}

\author{
Sueraya Che Haron ${ }^{1 *} \quad$ Khadijah Khalilah Abdul Rashid ${ }^{1} \quad$ Sabrina Haron ${ }^{2}$ \\ Arifin Mamat ${ }^{1} \quad$ Nurazzelena Abdullah ${ }^{1}$ \\ 1.Faculty of Education, International Islamic University Malaysia \\ 2.CITRA centre, National University Malaysia
}

\begin{abstract}
The COVID-19 pandemic in 2020 has caused a major transformation in the education system around the world. Due to the closure of schools and other learning institutions, the teaching and learning that were once face to face are now conducted online. Sudden change of education landscape has put educators and students in harrowing time. This paper reviews literature to find out the challenges faced by educators when teaching online. The results reveal that all educators around the world are facing intrinsic challenges, such as little or no knowledge, skills and experience in the implementation of online teaching, as well as extrinsic challenges such as students having no Internet access and coverage and own no proper gadgets. It is found out that the biggest challenge faced by most local educators as compared to their counterparts in some parts of the world is their lower level of readiness in facing the transition from teaching traditionally to online.
\end{abstract}

Keywords: COVID-19, pandemic, online teaching, challenges in online teaching, readiness in online teaching DOI: $10.7176 / \mathrm{JEP} / 12-2-06$

Publication date: January $31^{\text {st }} 2021$

\section{Introduction}

It has been a norm in Malaysia that teaching and learning in primary and secondary schools are done face to face in the classroom. It is not deniable that ICT tools such as computers, projectors and so on are provided in the schools, but the use is restricted due to insufficient tools and Internet access, therefore not everyone gets to benefit them on frequent basis. The proof can be seen from the 1Bestarinet program, a virtual learning platform in schools introduced to enhance ICT usage among teachers and was not thoroughly adopted in most schools (Simin Ghavifekr, Tanusha Kunjappan, Logeswary Ramasamy, Annreetha Anthony, 2016). This scenario does not only happen in Malaysia but also in other parts of the world where ICT tools are considered as add-ons to classroom teachings, activities, projects, workshops and seminars (Sakilandeswari, 2020), (Johannes Konig, Daniela J. JagerBiela, Nina Glutsch, 2020). In other words teachers are so used to traditional teaching and most of the time they are able to survive without the ICT tools. This is not to say that teachers do not acknowledge the value and benefits of ICT tools but the challenges they face during the usage outweigh the benefits. Similar situation is observed in the local universities as Prof Datuk Mohammad Shatar Sabran, the vice chancellor of Sultan Idris Education University (UPSI) mentioned that the online education system in the universities has not reach its optimum level even though internet access is not a problem. Most people prefer face to face to virtual. In the West on the other hand they are more serious about using ICT tools in teaching and learning and the best part is they have built the system (Mediapermata, 2020)

In 2020 however, the spread of COVID-19 has suddenly and terribly changed the norms. Every sector be it politics, economics, social, cultural sectors are all affected including the education system. All educational institutions for all level, be it public or private were instructed to close their premises and resume the teaching and learning activities online. The closure of these educational institutions is unfortunately extended from time to time. This is considered as the safest option so far to break the infection chain which is believed to be "transmitted between people through respiratory droplets and contact routes" (WHO, 2020). In Malaysia, all curriculum and co-curricular activities in education involving mass gathering need to be abolished temporarily to create social distance and ensure safety of all students and teachers (Yusri Muzamir and Amin Jali, 2020), (Abdul Halim Abdullah, 2020). Students are not allowed to go to schools and campuses since middle of March when the number of positive cases was on the rapid rise. In such situation, students are not allowed to go to school thus teaching and learning were resorted to online platform. Malaysian educators who were once heavily conventional has now started to utilize online communication platforms like Google Classroom, Zoom, Microsoft Teams, Telegrams, variety of online quizzes, materials and videos and so on. This drastic change has exposed educators and students to a number of challenges in adopting and adapting to the new norm in teaching and learning.

\section{Online teaching: What is it all about?}

Traditionally, distance education has been more successful at delivering content and less successful at providing interactivity and implementing the creative use of technology. Even the Internet, with all its advertised potential for interactivity and connectedness, has often been used simply to deliver print-based materials (e.g., downloadable 
PDFs) or other similar forms of non-interactive courseware. Streamed video on the Internet is commonly used to deliver course lectures recorded in classrooms (Renee Wallace, n.d). This situation is the result of educators having little or no knowledge and experience in utilizing the ICT tools in teaching and learning processes (Gold, 2001). He further contends that to become an effective online professional educator, one must engage in online learning to understand the way it works, what is lacking and how it should be done.

A successful online engagement unlike the traditional ones requires different sets of technical and pedagogical competencies to engage in effective teaching practices in online courses (Cyrs \& Conway, 1997). What the field of educational technology has postulated for over 30 years is that in order to encapsulate the potential of technology for increasing student learning, professional educators must have direct knowledge of, and experience with, the technology being used; technology experience (Renee, n.d). Professional educators must shift their instructional perspectives to be effective in an online environment. They do not have to abandon their teaching philosophies but rather, find innovative ways to demonstrate and utilize them in an online environment. Teaching online is very different from traditional classroom practice. Rather than being a sage on stage in a traditional classroom, an online professional educator is more like a guide on the side i.e. as a facilitator or coach to his/her students (Renee, n.d). Moderating is maintaining a constant flow of content-focused interaction between students. Strategies include encouraging students to participate in discussions as well as individual and group learning activities; keeping discussions focused on specific content; drawing out multiple perspectives; and summarizing and synthesizing the salient points of discussions.

Based on the elaborated literature above, it can be understood that a successful online teaching and learning requires engagement between educators and learners. In other words, the teaching and learning should be done interactively. Engagement creates active interactions and the role of educators is no longer teaching but facilitating to promote the engagement as much as possible. Only then the online teaching and learning reach its true meaning. However the present concern is the possibility to reach this level of effectiveness in a short period in times of "emergency". The sudden change requires sudden struggle. Associate Professor Tunku Badariah in Utusan Malaysia (2020) says "it's a huge responsibility requiring high efforts to reach high level of technical ability. The kind of successful and meaningful online teaching and learning however exist in the classroom where the educators have strong ICT background, knowledge, skill and experience.

\section{Challenges faced by educators in online teaching during the pandemic}

Even before the pandemic, Simin Ghavifekr, Tanusha Kunjappan, Logeswary Ramasamy, Annreetha Anthony (2016) reported that the perception in implementing ICT tools in the classroom among school teachers was average whereas the challenges of using ICT tools in the classroom was high. As the result, the use of ICT tools in the teaching and learning among Malaysian teachers is average in comparison to teachers in the West. The main reason is due to lacking of resources, time, access and technical supports.

During the pandemic, the problems multiplied not only from the educators' side but also from the learners' side. Low rate of students' participation in online classroom, having no gadget and tools to join online classes are reported (Mediapermata, 2020). Haslindar (2020) explained that not all students have good Internet access in their homes especially in the villages and in the rural areas. For example Jason Thomas, Durie Rainer Fong (2020) mentioned in Sabah Internet access in rural areas has been an issue for years. Similar situation is reported in Indonesia. The condition of server and signal strength in some areas are not stable. Besides, economic factor related to the purchasing of the Internet quota is another problem. To ease the situation, three teaching media are used during Arabic language classes in IAIN Palangka Raya; WhatsApp group, Google Classroom and Zoom Cloud Meeting with minimal term of doing five times synchronous video conference within 30 minutes (Ahmadi \& Aulia, 2020). Even today, some students are still unable to adapt to the virtual classroom because of the situation that is far from similar to the normal classroom, with no Internet facilities and equipment. Also many of the students come from urban poor families where they do not have smartphones, laptops or computers at home. They are also deprived of Internet access. So it's difficult to optimize teaching and learning online. Some students are not able to perform and complete their homework due to no Internet issue (Letchmanan Kamalakannan, 2020). Some teachers try to maintain as much contact with students as possible through conversations on messaging application like WhatsApp and Telegram due to lack of Internet usage among students (Agatha Wong, 2020). She further explained, that there are also barriers among students who can access the Internet but choose to not respond and reply. In contrast to the developed country like America, according to National Career for Education Statistics (NCES) as of Fall 2001, 99\% of American public schools have access to the Internet (Renee Wallace,n.d).

Giorgi Basilaia and David Kvavadze (2020) concluded that the transition from traditional to online education systems during the first week of the lockdown at one private school in Georgia was successful. They further explained that none of the online lessons were cancelled or failed. The attendance of the students was between 94\%-98\%. The key method implemented by the school was immediate skills and system improvement where they provided immediate online training to teachers in using relevant ICT tools for the teaching and learning. The school also reduced the duration of each lesson to avoid prolonged contact of the students with the computers/gadgets. 
Similar situation was reported in German where 70\%-90\% early career teachers managed to provide online lessons including maintaining communication with parents and students, introducing new contents, assigning tasks as well as giving feedbacks to students on regular basis (Johannes Konig, Daniela J. Jager-Biela, Nina Glutsch, 2020). Similarly in the US, the faculty members of Teacher Education, University of Brigham are found optimistic and positive with the sudden transition to online teaching. They are willing to revise their teaching for online delivery and their sense of hopes that their efforts would result in good online teaching, sharing power on technological expertise with students clearly signify their level of optimism (Ramona Maile Cutri, Juanjo Mena, Erin Feinauer, 2020).

On the contrary Sinar Harian (2020) reported that majority Malaysian lecturers are not ready to do online teaching effectively. Professor Dr Rosna Awang Hashim mentions that one of the reasons is most lecturers do not implement fully the online teaching before the pandemic and the university closure. She further explains that even though trainings have been given but still the number of lecturers willing to do it effectively is little. Supporting the comments, Associate Professor Tunku Badariah in Utusan Malaysia (2020) described that ICT laggards; those who refuse, not confident and not skillful in using these ICT tools for online teaching and learning do exist among those who are excitingly taking full responsibility to change the teaching from face to face to online. Even though many efforts have been made to promote the use of online teaching and learning in Malaysia, such as smart schools, the introduction of e-learning in higher institutions in 2006 and the introduction of national e-learning blueprint (DePAN), surprisingly they are still many educators who are not ready at all to move from traditional to online during the pandemic.

Online teaching and learning have yet to reach the level of satisfaction for educators and students. For some teachers, this is difficult because today, there are still many teachers who are lack of skills in the use of information technology to enable them to deliver teaching materials online (Anuar Ahmad, 2020), (Haslindar Nor Ismail, 2020), (Tunku, 2020), (Putra,2020), (Simin et.al, 2020), (JPK Malaysia, 2020). For some teachers, they need more preparation with teaching materials before implementing online teaching. Previously they only need to focus on preparing the teaching methods, now they need to increase the use of technology tools in their teaching aids because teachers need to teach using online pedagogical and assessment methods (Muhammad Talhah Ajmain@ Jima'ain1, Sharul Fitry Abdul Majid, Aminudin Hehsan, Zulkiflee Haron, Mohd Fauzi Abu-Husin, Juhazren Junaidi, 2020). Issues in lacking of pedagogical content knowledge (PCK) among educators which includes technical and administrative aspects of teaching online is not new. It was raised long ago by Shulman in the 80s and was continuously mentioned by later researchers such as Angeli and Valanides (2005), Kali, Goodyear and Markauskaite (2011), Ocak (2011), Ching, Hsu and Baldwin (2018), Chrysi Rapanta, Luca Botturi, Peter Goodyear, Lourdes Guàrdia, Marguerite Koole and Ching et al. (2018). Such lacking causes the educators to face complexity in the instructional situation and shortcomings in planning and organisation. The consequences of lacking the PCK can be seen from the recent studies that showed the efficiency of live online courses was unsatisfactory among students. However, when live online courses are combined with the flipped classroom, students' learning seemed to improve (Tao Tang, Atef M. Abuhmaid, Melad Olaimat, Dana M. Oudat, Maged Aldhaeebi \& Ebrahim Bamanger (2020). In addition, previous studies showed that flipped learning can help students to improve their performance in exams.

Prof. Rosna (2020) added another contributing factor, which is the lacking of instructional designer (ID) who will help the lecturers transforming the storyboard to be an interesting teaching and learning materials. Saddening to say in Malaysia the universities prefer the lecturers to learn the all these on their own. The burdens leaving the lecturers stressful and lessen their motivation to go online.

In addition to the above, the unreadiness could also be the result of the worsening of the pandemic where the sudden shift to online teaching is conceived as a crisis management rather than a teaching model they intentionally want to stick to in the future. Therefore, the adoption of online learning during COVID-19 crisis seems to be an abrupt response to the crisis which was not planned in advance thus it is also referred to emergency remote teaching (ERT) (Bozkurt \& Sharma, 2020), (Affouneh et al., 2020), (Tao Tang ,Atef M. Abuhmaid, Melad Olaimat, Dana M. Oudat, Maged Aldhaeebi \& Ebrahim Bamanger, 2020). Educators do not feel that this is permanent, hoping everything will go back to what it was and how it was.

Domestic responsibilities could be another potential reason for unreadiness. Switching to online teaching in the comfort of home is not easy especially for female teachers. Juggling domestic tasks such as managing household chores in between of online teachings demand high physical and mental strength. Despite all challenges Malaysian teachers are optimistic and positive with the change (Thesundaily,2020).

Along the same lines, taking attendance is one of the most difficult task to do online as educators wonder if the learners are really checked in or not (Sakilandeswari, 2020), Haslindar Nor Ismail (2020), (Agatha Wong 2020). Some language teachers share their concern on the effectiveness of teaching writing online (Sakilandeswari, 2020). Issues like students' attention in online classes and achievement, as well as the efficacy of online teaching are also raised ( Tao Tang, Atef M. Abuhmaid, Melad Olaimat, Dana M. Oudat, Maged, Aldhaeebi \& Ebrahim Bamanger (2020) 


\section{Discussion}

This paper reviews the challenges faced by the educators in online teaching during the pandemic that has impacted everyone around the globe in 2020. There are two main findings to be highlighted here.

The first one is the types of challenges faced by the teachers in teaching online can be categorized into two; extrinsic and intrinsic challenges. Extrinsic challenges as the name defines refers to challenges that comes from outside and educators have no control over it for example low rate of students' attendance and participation in online classroom, students having no gadget and tools to join online classes, students having no Internet access and so on.

Intrinsic challenges, on the other hand means challenges that comes from the educators themselves such as having no proper knowledge on resources and skills to conduct online classes, having no proper skills in using ICT tools, domestic tasks of the teachers such as household chores as the results of working from home, and effectiveness of the delivery as well as objectivity of the online assessment, limited time to plan and strategize online lessons, limited access and lack of technical supports.

Extrinsic and intrinsic challenges halt the smoothness of online teaching and learning as teachers cannot perform an effective online lesson if they have no proper knowledge, training, resources and skills on how to go about doing it. Similarly the lesson itself is hardly meaningful with less attendance and less participation and interaction by the students.

It is also observed that educators face similar challenges in online teaching. However, the biggest challenge as stated in most literature is the level of readiness and optimism among the educators to accept and implement the new norm in teaching and learning. It is undeniable that educators in the West show higher optimism and positivity than educators in Malaysia. They also show faster acceptance and willingness to adjust to the change compared to Malaysian teachers. Earlier reports in the West show higher percentage of classes conducted without failure, immediate trainings on handling the online teaching and learning, very high rate of attendance in online classrooms and immediate improvement to the online classroom based on feedbacks even in the first week. As for Malaysian teachers, as the time goes by, they also accept the fact that they have to transition to online delivery despite all the hiccups and difficulties faced by them throughout the journey.

This slight difference may be caused by the readiness of teachers in using ICT tools and the availability of the tools and trainings for the teachers before the pandemic. Schools in the developed countries are mostly well equipped with Internet access. ICT tools are widely available in the schools, and that implies teachers at the schools at least have been trained to utilize the tools in their teaching and learning. In other words they are much more ready extrinsically as well as intrinsically. The system despite of hiccups here and there is already there waiting to be used. As for the Malaysian teachers, chaos happened in the very first phase of the lockdown. Challenges such as limited Internet access, not knowing how to operate the online deliveries, lacking of technical supports, lacking of trainings are constantly reported in the news. In fact this is not the case during the pandemic only. It was reported earlier in several studies before the pandemic. Most teachers show average perceptions towards the utilization of ICT tools in the teaching and learning but high in challenges in using ICT tools. The average rate of perception may be caused by less readiness extrinsically as well as intrinsically. If only they do not face many challenges in trying to use the tools, maybe the perception would be higher. If only they had enough trainings, they had freedom to use the tools not only their perception increases but they appreciate it even more.

\section{Conclusion}

From the review and discussion it can be concluded that teachers, students and the system are three most important components to ensure smooth running and effective online teaching and learning especially during the closure of school. These three components are not new to be discussed. However for this particular moment these three become highly crucial for everyone's attention. By which without proper action, education during the pandemic is just means to fill up students' time at home and completing the syllabus. Education will be more meaningful when the teachers play their role to facilitate learning and not leaving students with the Youtube to understand the lessons and answer the questions that follow. The challenge is real as well as the struggle.

\section{References:}

Abdul Halim Abdullah. (2020, Mac 28). Covid-19 Buka Mata Warga Penddikan, Pelajar. Websit Link: https://www.bharian.com.my/rencana/komentar/2020/0 3/670374/covid-19-buka-mata-warga-pendidikpelajar.

Agatha Wong. (2020, April 3). Guru Sukar Laksana Pembelajaran Secara ‘Online’ Ketika PKP, oleh Jason Thomas dan Durie Rainer Fong di laman FMT. Website Link: https://www.freemalaysiatoday.com/category/bahasa/20 20/04/03/guru-sukar-laksana-pembelajaransecaraonline-ketika-pkp/

Ahmadi, Aulia Mustika Ilmiani (2020) The use of teaching media in Arabic language teaching during Covid-19 pandemic: Dinamika Ilmu, 20 (2), doi:http://doi.org/10.21093/di.v20i2.2515 
Bani Hidayat Mohd. Shafie (2020) Pelaksanaan PdPc dalam talian (OLL) semasa perintah kawalan pergerakan (PKP) fasa 1 dan 2 Covid-19: Jurnal Dunia Pendidikan, 2 (2), 213-221.

Basilaia, G., \& Kvavadze, D. (2020). Transition to online education in schools during a SARS-CoV-2 Coronavirus (COVID-19) pandemic in Georgia: Pedagogical Research, 5(4), em0060. https://doi.org/10.29333/pr/7937

Chrysi Rapanta, Luca Botturi, Peter Goodyear, Lourdes Guàrdia, Marguerite Koole (2020) Online university teaching during and after the Covid-19 crisis: Refocusing teacher presence and learning activity: Post Digital Science and Education, 2, 923-945.

Cyrs, T.E., \& Conway, E. (1997). Teaching at a distance with the merging technologies: An instructional systems approach. Las Cruces, NM: Center for Educational Development, New Mexico State University.

Emory McLendon, Peter Cronk (1999) Rethinking academic management practices: A case of meeting new challenges in online delivery: Journal of Distance Learning Assessment, 2 (1).

Gold, S. (2001). A constructivist approach to online training for online teachers. Journal of Asynchronous Learning, $5(1), 35-57$.

Jacqueline L. Rosenjack Burchum, Cynthia K. Russell, Wendy Likes, Cindu Adymy, Teresa Brit, Carolyn Driscoll, J. Carolyn Graff, Susan R. Jacob, Patty A. Cowan (2007) Confronting challeneges in online teaching: The WebQuest solution: MERLOT Journal of Online Learning and Teaching, 3 (1), 40-53.

Jason Thomas, Durie Rainer Fong. (2020, April 3). Guru sukar laksana pembelajaran secara 'online' ketika PKP. https://www.freemalaysiatoday.com/category/bahasa/2020/04/03/guru-sukar-laksana-pembelajaransecaraonline-ketika-pkp/

Johannes Konig, Daniela J. Jager-Biela, Nina Glutch (2020) Adapting to online teaching during Covid-19 school closure: teacher education and teacher competence effects among early career teachers in Germany: European Journal of Teacher Education 43 (4), 608-622

Kamalakannan Letchmanan. (2020, April 3). Guru Sukar Laksana Pembelajaran Secara 'Online’ Ketika PKP oleh Jason Thomas dan Durie Rainer Fong di laman FMT. Website Link: https://www.freemalaysiatoday.com/category/bahasa/20 20/04/03/guru-sukar-laksana-pembelajaransecaraonline-ketika-pkp/

Mei Jung Wang, Ka I Ip (n.d) Tasks and challeneges faced by teachers in handling an online project: Asian EFL Journal, 12 (4).

Muhammad Talhah Ajmain@ Jima'ain, Sharul Fitry Abdul Majid, Aminudin Hehsan, Zulkiflee Haron, Mohd Fauzi Abu-Husin, Juhazren Junaidi (2020) Covid-19 The benefits of IT functions in industrial revolution 4.0 in the teaching and facilitation process: Journal of Critical Reviews, 7.

Ramona Maile Cutri , Juanjo Mena \& Erin Feinauer Whiting (2020) Faculty readiness for online crisis teaching: transitioning to online teaching during the COVID-19 pandemic: European Journal of Teacher Education, 43:4, 523-541, DOI10.1080/02619768.2020.1815702

Renee Wallace (n.d) The challenges of effective online instruction and student learning, Florida A\&M University, Tallahasee, Florida

Simin Ghavifekr, Thanusha Kunjappan, Logeswary Ramasamy, Annreetha Anthony (2016) Teaching and Learning with ICT Tools: Issues and Challenges from Teachers' Perceptions: Malaysian Journal of Education Technology, 4 (2), 38-54

Tao Tang, Atef M. Abuhmaid, Melad Olaimat, Dana M. Oudat, Maged Aldhaeebi \& Ebrahim Bamanger (2020): Efficiency of flipped classroom with online-based teaching under COVID-19, Interactive Learning Environments, DOI: 10.1080/10494820.2020.1817761

Tita Beaven, Martina Emke, Pauline Ernest, Aline Germaine-Rutherford, Regine Hamppel, Joseph Hopkins, Mateusz Milan Stanojevic, Ursula Stickler (2010) Needs and challeneges for online language teachers-the ECML project dots: Teaching English with technology_Developing online teaching skills special issues 10 (2), 5-20.

Tunku Badariah, (2020) Kita patut lebih kreatif https://www.utusan.com.my/nasional/2020/11/kita-patut-lebihkreatif-inovatif/

Yusri Muzamir dan Amin Jali. (2020, April 6). COVID-19: Sesi Persekolahan Dicadang Dipinda. Website Link: https://www.bharian.com.my/berita/nasional/2020/04/6 dipinda

73619/covid-19-sesi-persekolahan-dicadang-

Zahiah Kassim, Abdul Razaq Ahmad (2010) E-pembelajaran: evolusi internet dalam pembelajaran sepanjang hayat: Proceedings of Regional Conference on Knowledge Integration in ICT, 209-216.

Cabaran pengajaran secara dalam talian https://mediapermata.com.bn/cabaran-pengajaran-secara-dalam-talian/

Cabaran Pembelajaran Online - Cadangan Mengatasinya http://jpkmalaysia.com/cabaran-pembelajaran-onlinecadangan-mengatasinya/

Cabaran mengajar dalam talian https://www.sinarharian.com.my/article/76874/BERITA/Nasional/Cabaranmengajar-dalam-talian

Five challenges of online teaching and how to rise above them https://www.3plearning.com/blog/5-common- 
pitfalls-distance-teaching-avoid/

Overcoming

the

challenges

of

online

teaching https://www.teachingenglish.org.uk/blogs/sakilandeswari/overcoming-challenges-online-teaching

PdP dalam talian beri cabaran dan pengalaman baru https://www.utusanborneo.com.my/2020/04/11/pdp-dalamtalian-beri-cabaran-dan-pengalaman-baharu

The challenges of sudden digital demand https://teachformalaysia.org/stories/the-challenges-of-the-suddendigital-demand/

Virtual education and its challenges for teachers https://www.thesundaily.my/local/virtual-education-and-itschallenges-for-teachers-HB2416944 